\title{
JURIANAI
}

Jurnal Pendidikan Ekonomi

$\therefore$ JUR KAIMI

VOLLME

5
NOMOR

2

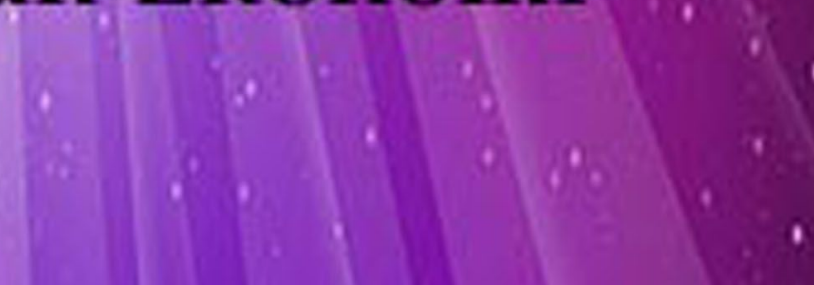




\title{
JURKAMI: Jurnal Pendidikan Ekonomi
}

http://jurnal.stkippersada.ac.id/jurnal/index.php/JPE

JURKAMI Volume 5, no 2, 2020

\section{MEMBANGUN JIWA WIRAUSAHAWAN (ENTREPRENEURSHIP) MENJADI MAHASISWA PENGUSAHA (ENTREPRENEUR STUDENT) SEBAGAI MODAL UNTUK MENJADI PELAKU USAHA BARU}

\author{
Emilia Dewiwati Pelipa ${ }^{1}$, Anna Marganingsih ${ }^{2}$ \\ STKIP Persada Khatulistiwa Sintang, Indonesia ${ }^{12}$ \\ Email: pelipaemilia@gmail.com ${ }^{1}$, amargningsih@gmail.com ${ }^{2}$
}

Diterima: 23 Oktober 2020; Disetujui: 29 Oktober 2020; Diterbitkan: 1 November 2020

\begin{abstract}
Entrepreneurship is a generator for the development of a nation, the more citizens who pursue entrepreneurship, the more the economic turnover of a country. Educated people are expected to play a role in advancing the economy. However, the problem that often occurs after graduating college graduates tends to be looking for work rather than creating jobs for themselves. Meanwhile, the absorption capacity of private and government agencies is very limited, resulting in a long waiting period to get a job. To anticipate this, it is necessary to build an entrepreneurial spirit in students since they are still in college so that they can become entrepreneurial students. Based on the results of the research, the results of the data analysis showed that the value of $T_{\text {count }}=4.56>T_{\text {table }}=2.052$, this shows that there are differences in student entrepreneurial abilities before and after treatment. After the treatment, the entrepreneurial ability of students increased.
\end{abstract}

\section{Keywords: Entrepreneurship, Entrepreneur Student}

Abstrak: Berwirausaha merupakan generator pembangunan sebuah bangsa, semakin banyak warga negara yang menekuni bidang wirausaha semakin laju perputaran roda perekonomian suatu negara. para sarjana sangat diharapkan perannya dalam memajukan perekonomian. Namun persoalan yang sering terjadi setelah lulus kuliah para sarja cenderung akan mencari pekerjaan dari pada menciptakan lapangan pekerjaan untuk dirinya sendiri. Sementara daya serap instansi swasta mau pun pemerintah sangat terbatas sehingga menimbulkan lamanya masa tunggu untuk mendapatkan pekerjaan. Untuk mengantisipasi hal ini maka perlu dibangun jiwa wirausaha pada mahasiswa sejak masih kuliah agar dapat menjadi mahasiswa pengusaha. Berdasarkan hasil penelitian hasil analisis data diperoloeh nilai $\mathrm{T}_{\text {hitung }}=4,56>$ $\mathrm{T}_{\text {tabel }}=2,052$, ini menunjukkan terdapat perbedaan kemampuan berwirausaha pada mahasiswa sebelum dan sesudah perlakuan. Setelah perlakuan kemampuan berwirausaha pada mahasiswa semakin meningkat.

\section{Kata Kunci: Wirausahawan, Mahasiswa Pengusaha}


126 | Emilia Dewiwati Pelipa, Anna Marganingsih, Membangun Jiwa Wirausahawan...

PENDAHULUAN

Berwirausaha memberikan manfaat bagi diri sendiri dan juga bagi orang lain, karna dengan berwirausaha dapat menciptakan lapangan kerja baru. Berwirausaha merupakan generator pembangunan sebuah bangsa, semakin banyak warga negara yang menekuni bidang wirausaha semakin laju perputaran roda perekonomian suatu negara. Untuk itu membangun jiwa wirausahawan (entrepreneurship) merupakan suatu hal yang sangat penting. Jiwa wirausaha adalah jiwa kemandirian untuk mencari sebuah sumber penghasilan dengan membuka usaha ataupun menyalurkan kreatifitas yang dimiliki sesorang untuk kemudian dijadikan sebuah lahan untuk mencari penghasilan.

Para "educated people" seperti para sarjana sangat diharapkan perannya dalam memajukan perekonomian. Namun persoalan yang sering terjadi setelah lulus kuliah para sarja cenderung akan mencari pekerjaan dari pada menciptakan lapangan pekerjaan untuk dirinya sendiri. Sementara daya serap instansi swasta mau pun pemerintah sangat terbatas sehingga menimbulkan lamanya masa tunggu untuk mendapatkan pekerjaan. Untuk mengantisipasi hal ini maka perlu dibangun jiwa wirausaha pada mahasiswa sejak masih kuliah agar dapat menjadi mahasiswa pengusaha (entrepreneur student). mahasiswa pengusaha (entrepreneur student) yang berhasil dapat memberikan manfaat bagi pihak lain, karna memiliki keahlian menyediakan produk yang menjadi kebutuhan masyarakat serta dapat menciptakan lapangan pekerjaan untuk dirinya sendiri dan orang lain.

$\begin{array}{rrr}\text { Sebagai } & \text { upaya } & \text { mewujudkan } \\ \text { entrepreneur } & \text { student } & \text { diperlukan }\end{array}$
pendampingan dan pembentukan bagi mahasiswa semasa kuliah untuk membangun jiwa wirausahanya. Jiwa kewirausahaan ditanamkan sejak seseorang mulai sadar bahwa uang itu penting dan seseorang tersebut memiliki keterampilan atau sesuatu hal seperti barang atau jasa yang bisa dijual, sesorang akan belajar untuk lebih mandiri, berfikir kritis, dan maju apabila ditanamkan jiwa kewirausahaan sejak dini, kerena dia akan berfikir tentang bagaimana mengolah hasil dari keterampilan ataupun hasil pembelajaran yang selama ini dilakukan untuk dijadikan sebuah karya yang dapat dijual, entah itu makanan, pakaian, jasa, atau barang-barang lain.

Semangat berwirausaha dikalangan mahasiswa harus dibudayakan. Semangat bisa ditimbulkan dengan menanamkan kesadaran dalam berusaha. Kemandirian dapat dibina dengan menanamkan keterampilan dan pengetahuan. Pengalaman dapat ditimba melalui 
aktivitas di lapangan, dan kreativitas dapat timbul melalui aktivitas dan keinginan untuk melakukan inovasi, sedangkan kemampuan manajemen dalam diri wirausahawan perlu dipersiapkan melalui pengenalan, penghayatan, dan penerapan IImu Kewirausahaan. Oleh karena itu perlu pemahaman mengenai kewirausahaan yang dimulai sejak dini baik dilingkungan pendidikan maupun dilingkungan keluarga. Dengan demikian diharapkan di masa yang akan datang bangsa Indonesia tidak hanya memiliki manusia berpendidikan formal tetapi juga memiliki jiwa kewirausahaan yang dapat membawa Indonesia menjadi negara maju.

Tujuan penelitian ini agar mahasiswa dapat memahami konsep, strategi dan karakteristik yang harus dimiliki untuk menjadi mahasiswa pengusaha (entrepreneurship student), dan Agar mahasiswa dapat memulai sebuah usaha

\section{KAJIAN TEORI}

Menurut Suryana ( dalam Suharyono 2017) Istilah kewirausahaan berasal dari terjemahan entrepreneuship yang dikenal dengan between taker atau go between yang pada abad pertengahan digunakan untuk menggambarkan seorang aktor yang memimpin suatu proyek produksi. Secara umum kewirausahaan diartikan sebagai suatu sikap, jiwa dan kemampuan untuk menciptakan sesuatu yang baru yang sangat bernilai dan berguna bagi dirinya dan orang lain.

Menurut Schumpeter (dalam Kurniati 2015) wirausaha adalah orang yang mendobrak sistem ekonomi yang ada dengan memperkenalkan barang dan jasa yang baru dengan mengombinasikan caracara baru untuk menciptakan bentuk organisasi baru atau mengolah bahan baku baru. Wirausahawan yang berhasil, salah satu kuncinya memiliki kepribadian yang unggul. Kepribadian tersebut kadangkala membedakannya dari kebanyakan orang. Gambaran ideal seorang wirausahawan menurut Alma (2010: 21) adalah orang yang dalam keadaan bagaimanapun daruratnya, tetap mampu berdiri atas kemampuan sendiri untuk menolong dirinya keluar dari kesulitan yang dihadapi, termasuk mengatasi kemiskinan tanpa bantuan siapapun. Bahkan dalam keadaan yang biasa (tidak darurat), mampu menjadikan dirinya maju, kaya, berhasil lahir dan bathin.

Baum, Frese, and Baron (dalam Rosmiati 2015) menjelaskan bahwa motivasi dalam kewirausahaan meliputi motivasi yang diarahkan untuk mencapai tujuan kewirausahaan, seperti tujuan yang melibatkan pengenalan dan eksploitasi terhadap peluang bisnis. Motivasi untuk mengembangkan usaha baru diperlukan bukan hanya oleh rasa percaya diri dalam hal kemampuannya untuk berhasil, namun 
128 | Emilia Dewiwati Pelipa, Anna Marganingsih, Membangun Jiwa Wirausahawan...

juga oleh kemampuannya dalam

pengusaha: 1) Melibatkan proses mengakses informasi mengenai peluang kewirausahaan.

Seorang pengusaha merupakan seorang yang menggabungkan sumber daya, tenaga kerja, bahan baku, serta aset lain untuk menghasilkan nilai yang lebih besar dari sebelumnya, juga seorang yang mengenalkan perubahan, inovasi, dan tantangan baru. Hisrich (dalam Rosmiati 2015) mengemukakan bahwa kewirausahaan diartikan sebuah proses dinamis dalam menciptakan tambahan kekayaan oleh individu yang menanggung risiko utama dalam hal modal waktu dan/atau komitmen karier atau menyediakan nilai bagi beberapa produk atau jasa. Produk atau jasa mungkin dapat terlihat unik ataupun tidak, tetapi dengan berbagi cara nilai akan dihasilkan oleh seseorang pengusaha dengan menerima dan menempatkan keterampilan dan sumber daya yang dibutuhkan. Hisrich (dalam Rosmiati 2015) menjelaskan lagi bahwa kewirausahaan (entrepreneurship) adalah proses penciptaan sesuatu yang baru pada nilai menggunakan waktu dan upaya yang diperlukan, menanggung risiko keuangan, fisik, serta risiko sosial yang mengiringi, menerima moneter yang dihasilkan, serta kepuasan dan kebebasan pribadi.

Definisi kewirausahaan menekankan empat aspek dasar menjadi seorang penciptaan dan menciptakan suatu nilai baru 2) Menuntut sejumlah waktu dan upaya yang dibutuhkan 3) Melibatkan seseorang menjadi pengusaha, penghargaan yang paling penting adalah kebebasan, lalu kepuasan pribadi, 4) Pengusaha akan merespon dan menciptakan perubahan melalui tindakan. Tindakan kewirausahaan menyatu pada perilaku sebagai bentuk tanggapan atas keputusan yang didasarkan pada pertimbangan ketidakpastian mengenai peluang untuk mendapatkan keuntungan (Rosmiati 2015).

Menurut Suharyono (2017).Seorang wirausaha sekurang-kurangnya memiliki 12 (dua belas) karakteristik yaitu motif berprestasi, selalu perspektif, berdaya cipta tinggi, memiliki perilaku inovatif tinggi, memiliki komitmen dalam pekerjaan, memiliki etos kerja dan tanggung jawab, mandiri atau tidak tergantung pada orang lain, berani menghadapi resiko, selalu mencari peluang, memiliki jiwa kepemimpinan, memiliki kemampuan manajerial dan memiliki kemampuan personal.

Mayoritas bisnis yang muncul di era modern saat ini cenderung dimanfaatkan melalui media online yang sekarang disebut e commerce. Start-up, kata yang sering dipakai di era digital saat ini, Sheung (2014) menjelaskan 
JURKAMI: Jurnal Pendidikan Ekonomi

bahwa metode startup bisnis diikuti oleh inovasi tren teknologi. Startup bisnis mampu menumbuhkan atau menciptakan peluang baru bagi para generasi muda khususnya yang bersedia untuk beradaptasi dan mengubah model pasar tradisional ke pasar virtual. Model bisnis lama yang mulai berubah ke model bisnis online(startup) dimana inventaris digantikan oleh informasi dan produk digital menggantikan barang fisik.

Beier (2016) menyatakan bahwa proses pemasaran dalam dunia digital juga harus dipahami oleh pemilik start up digital, digital marketing secara umum dapat didefinisikan sebagai penggunaan teknologi digital yang terintegrasi. Definisi lain juga menjelaskan komunikasi yang ditargetkan dan terukur yang ditujukan untuk memperoleh dan mempertahankan pelanggan dan di waktu yang sama dengan membangun hubungan yang lebih dalam dengan mereka (Wymbs 2011). Pemasaran online saat ini dapat dilakukan dengan teknologi baru seperti smartphone dan aplikasi pendukungnya (Tiago danVerissimo 2014).

Ada dua belas Langkah untuk Memulai Usaha Baru menurut Dinas koperasi Usaha kecil dan menengah

a. Siapkan Mental; Hal pertama yang
JURKAMI Volume 5, no 2, 2020 | 129

harus disiapkan adalah mental. Mental pengusaha berbeda dengan karyawan. Karyawan cenderung menghabiskan gaji bulanannya. Sedangkan, pengusaha harus menginvestasikan sebagian penghasilannya untuk mendapatkan penghasilan yang lebih besar. Maka, ketika kita sudah memilih untuk membuka usaha, terapkanlah mental sebagai pengusaha.

b. Siapkan Modal; Apapun jenis usahanya, pasti memerlukan modal. Banyak pengusaha yang mengeluhkan modal. Sebenarnya, tak perlu dirisaukan. Dengan modal kecil pun Anda sudah bisa membuka usaha. Besarnya modal tergantung dari besar atau kecilnya usaha yang Anda jalankan.

c. Bidang Usaha; Tentukan bidang usaha yang akan Anda buka. Anda bisa memilih bidang usaha yang belum pernah ada atau yang sudah banyak. Pada awalnya, orang merasa ragu untuk mulai membuka usaha, baik bidang yang belum pernah ada maupun yang sudah banyak dilakukan.

d. Lokasi; Lokasi merupakan peran penting dalam membuka usaha. Lokasi yang ramai diyakini akan membuat usahamu cepat dikenal dan menarik banyak peminat. Pilih 
130 | Emilia Dewiwati Pelipa, Anna Marganingsih, Membangun Jiwa Wirausahawan...

lokasi yang strategis, yaitu dekat dengan tempat aktivitas masyarakat, kantor, sekolah, atau kampus.

e. Fokus; Fokuslah pada satu bidang usaha terlebih dahulu. Banyak pengusaha yang gagal saat mulai berkembang, karena tidak fokus pada peningkatan bisnis awal, melainkan terlalu banyak ingin mencoba bidang usaha lain.

f. Cari Pelanggan; Kenalkan bidang usaha Anda ke luar. Sebarkan informasi barang dagangan atau usaha jasa Anda ke semua orang, agar bisa mendapatkan klien.

g. Cara Berbisnis; Sebenarnya, berbisnis itu mudah, kok. Contohnya, barang seharga Rp1000, tugas Anda adalah menjualnya dengan harga lebih dari itu, misalnya Rp. 1.500. Intinya, dari sebuah barang, Anda bisa menjualnya dengan memperoleh keuntungan. Setelah itu, juallah barang tersebut sebanyak-banyaknya.

h. Pegawai; Pada awal membuka usaha, Anda hanya membutuhkan sedikit pegawai. Selain Anda sendiri yang mengurus usaha tersebut, Anda bisa melibatkan pasangan atau anggota keluarga yang lain untuk ikut mengelola. Tujuannya agar mereka dapat ikut merasa memiliki usaha tersebut. Setelah usaha Anda berkembang, Anda bisa mepekerjakan pegawai tambahan.

i. Perencana Keuangan; Keuangan untuk membuka bidang usaha, tak hanya terpaku pada modal awal. Ketika usaha sudah berjalan, Anda harus pandai mengatur alur keluar masuknya uang. Pisahkan keuangan bisnis dengan keuangan pribadi. Banyak pengusaha yang gagal karena keuangan pribadi dan bisnis, tercampur aduk.

j. Mulai; Sudah memikirkan segala sesuatunya, Kalau begitu langsung mulailai.

k. Risiko; Membangun bisnis, tentu saja ada risikonya. Namun, kalau Anda sudah menyadari risikonya, tidak ada yang perlu dikhawatirkan. Semakin maju usaha Anda, reputasi Anda semakin dipertaruhkan. Karena itu, sambil menjaga kelangsungan bisnis, Anda juga harus terus menjaga reputasi.

1. Antisipasi Kegagalan; Risiko kegagalan dalam berbisnis, selalu ada. Karena itu Anda dituntut untuk bersikap tegas dan cepat bertindak, terutama bila melihat sesuatu yang tak beres.

Sistem pengembangan usaha kecil dibangun dengan melalui pengembangan pendukung jasa pengembangan usaha yang terjangkau, semakin tersebar dan bermutu 
untuk meningkatkan akses usaha kecil terhadap pasar, dan sumberdaya produktif, seperti sumber daya manusia, modal, pasar, teknologi dan informasi termasuk mendorong peningkatan intermediasi lembaga keuangan. Sebagian besar pengusaha kecil di Indonesia mempunyai alasan berusaha karena adanya peluang bisnis dan pangsa pasar yang aman serta besar (Tambunan 2012:6). Akibatnya usaha kecil lebih banyak muncul karena kemandirian dalam menjalankan usaha, walaupun masih terjadi beberapa kegagalan karena belum memiliki kemampuan dalam menyelenggarakan kegiatan bisnis.

Kebijakan strategis dan terpadu untuk mengembangkan sektor usaha kecil, ditetapkan dengan harapan menjadikan usaha kecil sebagai kekuatan ekonomi mandiri, mampu memberi kontribusi yang signifikan terhadap pendapatan domestik bruto. Penguatan lembaga pembiayaan serta kebijakan strategis dalam mengembangkan usaha sektor kecil merupakan kekuatan ekonomi yang mandiri untuk terbentuknya usaha kecil yang tangguh dan sehat (Sukirman \& Indrayani 2014).

Pelaku usaha mikro belum mampu memanfaatkan pengelolaan manajemen organisasi, sehingga memerlukan adanya bimbingan pengelolaan manajemen untuk mewujudkan terbentuknya jiwa kewirausahaan (Sukirman 2010). Selain itu struktur organisasi kurang jelas sehingga berdampak pada ketidak jelasan dalam mewujudkan kemandirian usaha, yang akhirnya saling melempar tanggung jawab apabila terjadi permasalahan dalam menjalankan usaha. Pengelolaan lingkungan pada industri kecil belum dilaksanakan secara maksimal, kaitannya dengan keterlibatan karyawan, kinerja lingkungan, kinerja perusahaan dan perilaku kewirausahaan (Sukirman 2012).

Menurut (Yusleli 2011) Wirausaha adalah kemampuan yang dimiliki oleh seseorang untuk melihat dan menilai kesempatan-kesempatan bisnis; mengumpulkan sumber daya-sumber daya yang dibutuhkan untuk mengambil tindakan yang tepat dan mengambil keuntungan dalam rangka meraih sukses. Untuk mencapai kesuksesan, UMKM harus menerapkan program kewirauasahaan secara optimal yang antara lain: (1) Kreatif dan Inovatif, (2) Smart, (3) Pekerja Keras dan (4) Bertanggungjawab

\section{METODOLOGI PENELITIAN}

Metode yang digunakan dalam penelitian ini adalah metode kuantitatif dengan desain pre experimental design bentuk one group pretest-posttest design. Sampel dalam penelitian ini 28 orang mahasiswa anggota Unit kegiatan 
132 | Emilia Dewiwati Pelipa, Anna Marganingsih, Membangun Jiwa Wirausahawan...

Mahasiswa bidang Kewirausahaan STKIP

Persada Khatulistiwa Sintang. Alat pengumpul data yang digunakan adalah tes kreativitas berwirausaha. Analisis data menggunakan pengujian hipotesis komparatif untuk sampel berkorelasi

\section{HASIL DAN PEMBAHASAN}

Hasil

Membangun jiwa entrepreneurship mahasiswa anggota UKM kewirausahaan dilakukan dengan cara memberikan pelatihan dan penyuluhan berwirausaha secara berkala kepada mahasiswa, mahasiswa diminta untuk mempraktekkan materi yang sudah didapat dalam kegiatan pelatihan. Dengan cara memulai usaha sesuai pilihan masing-masing, hingga tercapai entrepreneur student yang memiliki usaha baru. Proses pelaksanaan kegiatan wirausaha yang dilakukan oleh mahasiswa di bimbing langsung oleh peneliti dalam naungan UKM kewirausahaan.

Berdasarkan hasil penelitian hasil analisis data diperoleh nilai $\mathrm{T}_{\text {hitung }}=4,56>$ $\mathrm{T}_{\text {tabel }}=2,052$, ini menunjukkan terdapat perbedaan kemampuan berwirausaha pada mahasiswa sebelum dan sesudah perlakuan. Setelah perlakuan kemampuan berwirausaha pada mahasiswa semakin meningkat.

\section{Pembahasan}

Membangun jiwa entrepreneurship mahasiswa dalam penelitian ini dilakukan dengan konsep entrepreneurship student, yang dilakukan adalah Pertama, Mahasiswa harus menyukai apa yang mereka lakukan. Jadi pilihlah ide bisnis sesuai dengan apa yang disukai. Karena jika mengerjakan apa yang disukai tidak akan membuat bosan. Salah satu penyabab gagalnya suatu bisnis yang baru dirintis adalah founder yang tidak memiliki konsep matang. Jika sudah mengetahui apa yang akan lakukan, langkah selanjutnya menguji ide bisnis dengan beberapa pertanyaan ini: Apakah produk atau jasa yang akan ditawarkan merupakan suatu kebutuhan di masyarakat?,Siapa yang membutuhkannya?, Apakah sudah ada produk atau layanan yang serupa?, Bagaimana cara menjualnya?. Sebenarnya dalam membuat suatu bisnis, ide tidak harus baru, kita hanya perlu menambahkan sesuatu yang membedakan bisnis kita dari yang lain, itu bisa menjadi suatu nilai plus.

Setelah tahu produk atau layanan yang ingin diproduksi, selanjutnya mengukur peluang bisnisnya. Pelajari target pasar, mencari tahu apa yang diinginkan pelanggan, kenali juga kompetitor. Hal ini dapat membantu mengembangkan strategi pemasaran yang sesuai. Langkah selanjutnya membuat rencana bisnis atau roadmap dalam 
menjalankan bisnis, menjabarkan tujuan bisnis dan menjelaskan bagaimana strategi mencapainya.

Langkah selanjutnya melakukan branding yaitu menciptakan persepsi dan citra berdasarkan pengalaman emosional pelanggan. Mencari nama bisnis yang menarik dan mudah diingat, usahakan terdengar bagus dan menyampaikan citra yang diinginkan, tambahkan juga komponen visual pada brand untuk memperkuat citra. Dari pilihan warna, grafis, jenis huruf dapat melengkapi gambaran kepribadian usaha yang dijalankan. Memanfaatkan teknologi digital untuk membuat web atau akun di media sosial untuk mempromosikan bisnis cara ini efektif untuk engage market sasaran. Melakukan Legalisasi bisnis untuk menghindari permasalahan hukum, disini mahasiswa diajarkan untuk mengurus ijin usaha.

Agar bisnis yang dijalankan oleh mahasiswa berjalan lancar dan tidak mempengaruhi kualitas perkuliahan; mahasiswa harus menerapkan beberapa strategi entrepreneurship student. Pertama mahasiswa harus mampu mengatur waktu, seimbangkanlah dalam menggunakan waktu, fokus berarti mengerjakan sesuatu dengan baik dan profesional, setelah selesai lakukan dengan baik dan profesional juga aktivitas lainnya. Aturlah waktu belajar, organisasi, dan bekerja.
Langkah kedua Buat Skala Prioritas menggunakan prioritas yang penting dan mendesak, sehingga tugas atau target dapat tercapai lebih cepat dan dengan waktu yang tidak terlalu mendesak. Buatlah kegiatan apa saja yang tergolong penting mendesak, penting dan kurang mendesak. Ketiga Belajar lebih Tekun dan bekerja lebih baik. Tekadkanlah untuk belajar dan bekerja keras dan lebih cerdas. Sehingga suatu saat hasil yang didapatkan lebih besar daripada energi yang keluarkan. Keempat jalin relasi dan tumbuhkan kepercayaan, dengan memiliki banyak relasi dapat mempermudah memajukan bisnis. Mahasiswa dapat saling berbagi pengalaman dan dapat saling membantu dalam hal memajukan bisnis yang dibangun.

Karakteristik yang harus dimiliki untuk menjadi mahasiswa pengusaha (entrepreneurship student) : pertama cerdas secara emosional, mampu menerima, menilai, mengelola, serta mengontrol semua emosi. Orang yang cerdas secara emosi akan bersikap lebih tegas dan mampu mengendalikan perilakunya sehingga bisa terbebas dari perilaku-perilaku negatif. Orang yang cerdas secara intelektual bisa gagal dalam membangun bisnis, tetapi jika memiliki kecerdasan secara emosi, peluang suksesnya menjadi lebih besar. Kedua niat dan tekad kuat: Saat pertama kali dalam 
memulai bisnis, pasti akan berhadapan dengan banyak hal baru yang belum ketahui sebelumnya, berhadapan dengan berbagai hambatan dan tantangan dalam dunia usaha; untuk itu diperlukan niat dan tekat yang kuat dalam menjalankan usaha supaya tidak cepat patah semangat.

Ketiga Disiplin Tinggi: Disiplin adalah salah satu karakter yang wajib dimiliki oleh seorang entrepreneur. Disiplin juga menjadi cerminan seseorang pekerja yang profesional. Jika ingin menjadi entrepreneur yang sukses, sudah sepantasnya mulai mendisiplinkan diri agar bisnis yang jalankan bisa terus berkembang. Dengan memiliki sifat disiplin, pekerjaan dapat diselesaikan tepat waktu. Keempat Memiliki Kemauan Keras: Dalam dunia bisnis, hambatan, rintangan, tantangan, dan masalah seolah menjadi hal biasa yang ditemui. Dengan memiliki mental dan karakter, serta kemauan yang keras untuk bisa sukses, seorang entrepreneur akan bisa melewati semua itu dengan lancar. Kemauan yang keras menjadi salah satu hal wajib yang harus dimiliki oleh seorang entrepreneur yang ingin sukses. Kelima Percaya pada Kemampuan Diri: Percaya terhadap kemampuan diri sangat diperlukan dalam menjalankan sebuah bisnis. Seorang entrepreneur yang memiliki karakter percaya pada kemampuan diri, akan lebih bisa mengendalikan keraguan dan kegelisahan dalam menjalani bisnis. Sebab, dengan kepercayaan diri yang tinggi, Anda akan bisa menentukan keberhasilan bisnis yang Anda jalankan, karena percaya diri menjadi cerminan seorang yang sukses.

Keenam Berani Mengambil Risiko: Seorang entrepreneur sebagai pemilik usaha seringkali dituntut untuk menentukan keputusan penting dalam bisnis yang sedang dijalankan. Tentunya ini akan menyangkut masa depan bisnis yang sedang dijalankan. Maka dari itu, seorang entrepreneur harus bisa berpikir matang-matang saat mengambil keputusan. Keputusan untuk berani mengambil risiko ini menjadi salah satu mental dan karakter seorang entrepreneur, jika terjadi risiko kerugian bisnis, maka harus lebih bijak lagi ketika mengambil keputusan agar kesalahan itu tidak terulang kembali. Ketujuh Pantang Menyerah: Seorang entrepreneur haruslah memiliki jiwa pantang menyerah. Karena dalam kenyataannya, bisnis yang dijalankan tidak akan semulus yang dibayangkan, banyak kejadian-kejadian di luar dugaan. Ketika hal buruk terjadi pada bisnis seperti kerugian, jiwa pantang menyerah inilah yang sangat diperlukan. Segeralah bangkit dan coba kembali, biarlah kegagalan kemarin menjadi pengalaman yang berharga. Kedelapan Jujur: Untuk membangun rasa percaya antar pelaku 
bisnis, cara yang paling tepat adalah dengan kejujuran. Karena kepercayaan tidak akan dibangun dari kebohongan. Kejujuran ini haruslah mulai dibangun dalam lingkungan bisnis. Jika tidak, maka bisnis dapat dipastikan tidak akan bertahan lama. Dengan adanya kejujuran di dalam bisnis, maka semua pihak tidak akan dirugikan.

Kesembilan Kreatif dan Inovatif: Memiliki karakter kreatif dan inovatif menjadi hal yang penting, karena persaingan di dunia bisnis yang sangat ketat. Kreatif adalah suatu sifat untuk mencari hal-hal yang baru dan inovatif adalah sifat yang selalu mencari solusi kreatif. Sehingga kreatif dan inovatif ini merupakan paket lengkap yang harus dimiliki jika ingin menguasai pasar dalam bisnis. Dengan menciptakan produk baru yang berbeda dengan produk lainnya, maka bisnis akan mempunyai nilai lebih di mata konsumen. Kesepuluh kemampuan untuk mengelola administrasi keuangan dengan baik: Administrasi keuangan secara umum memiliki fungsi untuk merencanakan, mengendalikan sumber daya keuangan dalam bisnis secara efektif dan efisien agar manajemen usaha tertata dengan baik. Kesebelas Ikhlas dan Bersyukur: mental dan karakter seorang entrepreneur adalah ikhlas dan bersyukur terhadap hasil yang didapatkan. Meskipun satu sisi seorang entrepreneur dituntut untuk memiliki tekad dan kemauan yang keras untuk bisa sukses. Namun di sisi lain, entrepreneur juga harus memiliki sifat selalu ikhlas dan bersyukur terhadap penghasilan yang di dapatkannya.

\section{PENUTUP}

Berdasarkan hasil dan pembahasan yang telah dipaparkan maka dapat ditarik kesimpulan sebagai berikut: 1) Untuk menjadi entrepreneurship student diperlukan kesadaran untuk membangun jiwa wirausaha pada diri sendiri; 2) Seorang entrepreneurship student harus memiliki konsep dalam menjalankan usaha yaitu memilih ide bisnis sesuai bakat dan minat, menguji ide bisnis yang sudah dipilih apakah akan menjanjikan profit atau tidak, mengukur peluang dan melakukan branding; 3) Strategi yang dapat diterapkan entrepreneurship student dalam menjalankan usaha yaitu, mampu mengatur waktu, skala prioritas, belajar lebih tekun, bekerja lebih baik dan menjalin relasi dengan banyak orang; 4) Karakteristik yang harus dimiliki entrepreneurship student antaralain: cerdas, memiliki tekad yang kuat, disiplin, kemauan keras, percaya pada kemampuan diri sendiri, berani mengambil resiko, pantang menyerah, jujur, kreatif, inovatif, mampu mengelola administrasi keuangan dengan baik, iklas dan bersyukur

\section{DAFTAR PUSTAKA}

Alma, Buchari. (2010). Kewirausahaan (edisi revisi). Bandung: CV Alfabeta. 
136 | Emilia Dewiwati Pelipa, Anna Marganingsih, Membangun Jiwa Wirausahawan...

Beier, Michael (2016): Startups'

Experimental Development of

Digital Marketing Activities. A

Case of Online-Videos. Social

Science Research Network

(SSRN) Electronic Journal, Paper:

2868449.

Edy Dwi Kurniati ( 2015). Kewirausahaan

Industri. Yogyakarta: Deepublish

Herawati Yusleli. (2011). Langkah

Wirausaha Dalam Meningkatkan

Dan Mengembangkan Usaha.

Jurnal Ilmiah Orasi Bisnis Edisi

Ke-VI.

Rosmiati.( 2015). Sikap, Motivasi, Dan

Minat Berwirausaha Mahasiswa.

JMK, VOL. 17, NO. 1

Sheung,Chia Thian. (2014). E-Business;

The New Strategies Ande-

Business Ethics, that Leads

Organizations to Success. Global

Journal of Management and

Business Research ( A ) Volume

XIV Issue VIII Version I Year

2014

Suharyono. (2017). Sikap Dan Perilaku

Wirausahawan. Jurnal Ilmu dan

Budaya, Vol. 40, No.56.

Sukirman. (2010). “Analisis pengaruh

faktor internal dan eksternal

terhadap kinerja usaha kecil yang

dikelola perempuan (dengan

pendekatan Balanced

Scorecard)." Jurnal Kinerja,

Bisnis dan Ekonomi 14 (3): 248-

62
Sukirman. (2012). "Analisis pengaruh kinerja lingkungan terhadap kinerja industri kecil.” Jurnal Dinamika Manajemen 3 (1): 1018.

Tambunan, Tulus. (2012) Usaha mikro kecil dan menengah di Indonesia (isu-isu penting). Jakarta: LP3ES.

Tiago, M. T. P. M. B., and Veríssimo, J.

M. C. (2014) "Digital Marketing and Social Media: Why Bother?,'Business Horizons 57(6), pp. 703-708.

Wymbs, C. (2011) "Digital Marketing: The Time for a New" Academic Major" Has Arrived," Journal ofMarketing Education33(1), 93106 